Sedition, Sexuality, Gender, and Gender Identity in South Asia

\title{
Sedition, Sexuality, Gender, and Gender Identity in
} South Asia

\section{Svati P. Shah}

\section{OpenEdition}

\section{Journals}

Electronic version

URL: http://journals.openedition.org/samaj/5163

DOI: $10.4000 /$ samaj.5163

ISSN: 1960-6060

\section{Publisher}

Association pour la recherche sur l'Asie du Sud (ARAS)

\section{Electronic reference}

Svati P. Shah, "Sedition, Sexuality, Gender, and Gender Identity in South Asia", South Asia

Multidisciplinary Academic Journal [Online], 20 | 2019, Online since, connection on 10 March 2021. URL: http://journals.openedition.org/samaj/5163 ; DOl: https://doi.org/10.4000/samaj.5163

\section{This text was automatically generated on 10 March 2021.}

\section{(c) $($ ) $\odot$}

This work is licensed under a Creative Commons Attribution-NonCommercial-NoDerivatives 4.0 International License. 


\title{
Sedition, Sexuality, Gender, and Gender Identity in South Asia
}

\author{
Svati P. Shah
}

1 The question at stake in this collection of essays is: how might we extend critiques of nationalist projects in South Asia by accounting for nationalism and political dissent in the imbrications, conflicts, aporias, elisions, and formations of "nonnormative" forms of gender and sexuality. ${ }^{1}$ These essays engage this project by focusing on the ways in which speech is being further regulated and sequestered by the state, especially when the state is confronted by its critics on policies that are increasingly repressive. These essays also engage the ways in which the problematic of speech is imbricated with, inflected by, and constituted within social and affective categories that are produced

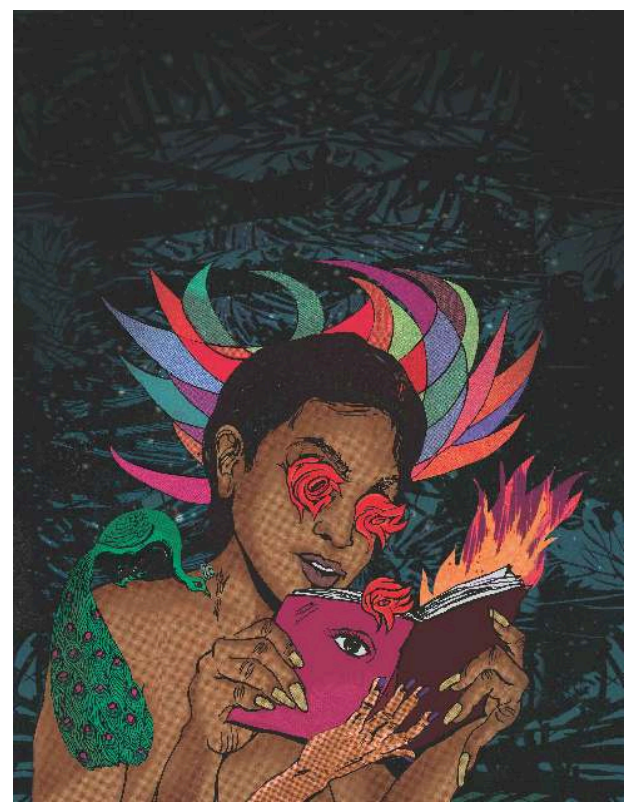
through rubrics of gender and sexuality in South Asia. Collectively, the contributors to this issue are interested in the ways in which laws that enable the state to penalize critical speech, like India's colonial era sedition law, have been used against citizens seeking to express their dissent to the exercise of state power, especially when that power veers toward impunity. While there are laws on the books throughout South Asia that resonate closely with the rubric of "sedition," this collection is less concerned with looking for resolute alignment between distinct national legal codes in the region than it is with how the problematics of dissent that implicate gender and sexuality are folded within accusations of "antinationalism," which specific imputations of "sedition" or "blasphemy" often sustain. To be sure, of particular interest here is how "anti-nationalism" creates a juridical foil 
to nation-loving citizens, via the "anti-national" subject. This means that we are interested in where and how policing, regulating and/or embracing "diversity" with respect to queer, trans and other identities and practices that emerge from the rubrics of gender and sexuality shore up or inhibit the rights of citizens to criticize their own governments. This interest emerges, in turn, from a longstanding set of inquiries within gender and sexuality studies on whether inhabiting "non-normativity" with respect to these rubrics necessarily indicates dissension with the status quo, if, indeed, it ever did (Warner 2000). These kinds of questions will gain new momentum in South Asia, now that "carnal intercourse against the order of nature with any man, woman or animal"-homosexuality, by proxy-has been decriminalized in India via the "reading down" of India's anti-sodomy law, Section 377 (Narrain 2018), with the hope that the law might be read down or eliminated in Sri Lanka, Bangladesh and Pakistan as well.

2 For the purpose of the discussions that the works in this issue engage, I begin this introductory essay with the observation that the critical space for thinking about national unity, belonging, and un-belonging have been historically and constitutionally generative for feminist, queer and trans* ${ }^{*}$ critique ${ }^{2}$ and vice versa. One axis for feminist and queer critique of the nation has necessarily been via critical engagement with the law, and the fundamental insight that the law enables, sustains and produces national subjects in the terms of gender and sexuality in everyday life. For example, if laws like those against sedition and blasphemy evince a discursive space that enables acts of extrajudicial, nationalist impunity, then that space of public discourse is also marked through gendered and sexual comportment and power. This is why, in addition to laws such as those governing sedition, which constrain speech acts, these authors are also interested in debates on laws that regulate gender and sexuality directly. These include the regime of "personal law" (Sharafi 2015) present throughout South Asia, which governs marriage and heritability, as well as the colonial-era anti-sodomy law, which remains in effect in Pakistan, Sri Lanka and Bangladesh. The problematics of personal law are one way we might access an interest in questions of temporality, juridicism, and the telos of progress, and the ways in which these are attached, for example, to the status of cisgender women (Mukhopadhyay 2015) and queer subjects in the postcolony. Expanding critical space to think through the juridical imbrications of sedition, personal law and anti-sodomy law, for example, is particularly consequential at a time when dissent, including anti-heteronormative dissent that is critical of caste-based endogamy, is pitted against the idea of national unity, rather than its being seen as integral to the constitution of a democratic polity.

\section{Sedition and anti-nationalism}

3 This collection proceeds from these foundational insights to seek a means of interrogating the ways in which questions of sexuality and gender have been articulated in relation to governance, materialism, inequality, and dissent in South Asia. For some of the authors represented here, this means using an explicitly "intersectional" frame that maps specific relations between distinctly theorized categories of analysis. For others, this means enabling critiques of gender, sexuality, materialism, secularism, and governance, where these are not necessarily held apart as distinct or primary objects of knowledge (Wiegman 2012). All of these authors are engaged in an exercise that brings to bear questions of sexuality and gender on those of 
caste, class and governance, within the careers and contexts of various forms of nationalism in South Asia.

Thus, these papers mark the intersections of two contemporaneous phenomena: firstly, the ways in which the term "anti-nationalist" is being deployed as both an epithet and, at times, as grounds for arrest in South Asia, and, secondly, the ways in which the politics, legal discourses, and everyday comportment of gender and sexuality continue to change rapidly in South Asia, as they do throughout the world. Critiquing these coincident phenomena requires particular attention to the ways in which gender and sexuality are categorically, affectively, aesthetically, and juridically rendered in relation to governance in general, and in relation to the ways in which speech and dissent are under specific forms of attack across the region today, in particular. This interest in contemporary forms of sequestering or even eliminating certain speech acts does not indicate a belief that the regulation of speech is the same across South Asia (see below), nor that the kinds of official and unofficial regulation, surveillance and sequestration of speech that we are concerned with here are necessarily being understood as "new." In other words, the concern with the contemporary here does not imply a belief that there was once a time when dissent was, in general, a mode of speech protected in law and in practice that is now being rapidly stamped out. Rather, our attention to the contemporary moment in which the rubric of "anti-nationalism" is used to regulate dissent mobilizes an interest in how these forms of regulation and control often resonate with historically robust manifestations of the state controlling criticism of its policies.

\section{'Gay saathiyon ko lal salaam' ('Red salute to gay comrades')}

The initial provocation for the symposium from which this volume is derived was the efflorescence of activism in response to the Indian government's crackdown against freedom of speech in a number of its central universities, ${ }^{3}$ beginning in 2015. I say "initial" because a symposium dedicated to the crisis of speech in India's most prestigious public universities would necessarily interrogate a different, though overlapping, set of issues to those discussed in this collection of essays. Rather, the symposium and, therefore, this volume, grew out of the questions that Indian student activists were asking at the time regarding the government's use of the death penalty and its use of extrajudicial force to suppress minority franchise, and out of an engagement with the critical response to the physical and rhetorical attacks that these activists faced. At the same time, the volume has also arisen from questions that are asked by the relatively new activist coalitions and rhetoric that emerged amongst leftists and progressives seeking to fight against the government's actions during this period. For example, shouting slogans like "gay saathiyon ko lal salaam" at campus protests indicated a new chapter for left organizing in India, to be sure, while also showing the need to theorize the relationships between queer and trans subjectivity, non-normativity, and political dissent.

Two of the most widely publicized examples of the Indian government cracking down on its critics in the university were at the University of Hyderabad, in the wake of Dalit ${ }^{4}$ graduate student Rohith Vemula's suicide in early 2016 (Sukumar 2016), and at Jawaharlal Nehru University (JNU) in New Delhi during that same year. ${ }^{5}$ The attacks against student organizing in each of these instances were initiated or intensified in 
response to on-campus student protests against the implementation of the death penalty in cases where people had been convicted of "anti-national" crimes on the basis of highly questionable evidence. At the University of Hyderabad, a combination of actors on campus, working in tandem with the federal Ministry of Human Resource Development, responded to protests led by the Ambedkar Students Association (ASA) in 2015 against the 2007 hanging of Yakub Memon for the 1993 bombings in the city of (then so-named) Bombay (Grover 2015). Rohith Vemula, a Dalit graduate student, was a member of the ASA, an organization comprised of non-upper-caste students dedicated to fighting for the rights of Dalits on campus. Vemula served as an organizer of these protests, and it is widely believed that his suicide was facilitated by the retaliation he experienced from university administrators, who cut off his student fellowship and evicted him from university housing. The retaliation that Vemula suffered caused his supporters to label his suicide an "institutional murder." At JNU, a similar combination of state and non-state actors also responded with violence, in tandem with visible police presence on campus, when another campus protest against the use of capital punishment took place. This protest, led by a leftist student group, sought to highlight the cases of Afzal Guru, who was convicted for playing a role in the 2001 attack on the Indian Parliament (Zia 2018), and the much earlier case of Maqbool Bhatt, a Kashmiri separatist and co-founder of the Jammu Kashmir Liberation Front, who was executed by the state in 1984. At this writing, the crackdown against JNU has been ongoing since February 2016, (JNUTA 2017) with several student leaders of these protests still facing formal charges of sedition (Manral 2018). To these two instances of the Indian state's repression of speech we can add a great many others, ${ }^{6}$ including violent attacks led by the BJP's youth wing-the Akhil Bharatiya Vidyarthi Parishad (ABVP) -against a 2015 screening of the documentary Muzaffarnagar Baaqi Hai in Kirori Mal College, Delhi University (Pal 2015). ${ }^{7}$ The film shows how communal "riots" in Muzaffarnagar, Uttar Pradesh, in 2013 were contrived by Hindu fundamentalist political parties in a bid for electoral power, a strategy that has been called "the Gujarat model."

There are a number of obvious similarities amongst these examples of state-sponsored suppression of student activism in India, the main ones being that these are all instances which demonstrate the ways in which hatred against Muslim and Dalit minorities is used to consolidate Hindu nationalist electoral power, in a context where the Hindu right "family" of political parties-the Sangh Parivar-seems to be focused on obtaining electoral success by legal and extra-legal means. While the reaction to these campus protests received a great deal of attention in the media (Farooq 2016), in activist reports (PUDR), and in scholarly critiques (Sukumar 2016), what has perhaps received less widespread attention is the support that these student protests received from a wide range of activist groups and "communities," including women's groups, and queer and transgender students, faculty, and organizations. Their support was neither unusual nor particular, but it does give us an opportunity to ask what is significant about the recognizable presence in all of these struggles of feminists and of lesbian, gay, bisexual, transgender, queer, and intersex (LGBTQI) activists? And what, therefore, is there to say on the relationship between feminist and queer scholarship on the links between struggles for freedom of speech and the right to protest, and the campaigns that feminists have waged on sexual harassment, bodily autonomy and integrity, consent, and sexual freedom for decades?

By underscoring the preceding events in relation to this volume, I do not mean to suggest that these are the only universities in South Asia where confrontations with 
the state have been taking place, nor to imply that these events represent the most egregious excesses of state power in the region. Most importantly, these events must be read against the long history of state suppression of critical speech deployed against impoverished, non-metropolitan, landless people all over South Asia who are racialized as "lower caste," "tribal" and as "religious minorities." Rather than claiming that these events are particular in some way, I discuss them here as a means of pointing to certain obvious and instructive similarities amongst these attacks against student organizing on each campus. That they all involved a self-described "nationalist" response to student protests against the use of the death penalty, and that they involved local police and proxy student organizations for the ruling Hindu nationalist Bharatiya Janata Party, shows that, while all spaces of critique and dissent are vulnerable, a tandem judicial and extrajudicial attempt was being made at that time to sequester a specific area of discussion and critique from public view. This was, in other words, a real effort toward "the muting of critical discourse and public debate" (Butler 2004). In South Asia, this area of "sequestered" critique may be broadly defined as critiques that are seen to question the territorial integrity of the nation, by questioning the ways in which borders are drawn, and by questioning the various means that the state uses to maintain its territorial integrity, including its use of the death penalty. To be sure, such critiques also necessarily question what is gained from this version of national territoriality, and by whom, inasmuch as they document police and paramilitary violence against citizens exercising their right to protest.

\section{The problematic of South Asia}

This particular combination of papers draws on South Asia as a repository of shared history, including juridical history via the legacy of legal codes first drafted during the British Raj by imperial administrators in the late nineteenth century, without implying that there is single unifying model for problematizing nationalism and "antinationalism" across South Asia. Due to the publicity attached to the recent "reading down" of India's anti-sodomy law, Section 377 (Safi 2018b), it is at present one of the more widely discussed of these anachronistic "legacy" laws shared across South Asia, although it is certainly not the only law of its kind to have remained in force for so long. While the end of the criminalization of consensual "unnatural" sex between adults is a welcome change, particularly as it was won on the heels of a 25-year-long campaign (Sahni 2018), it does raise questions about how much freedom it portends when dissent itself seems to be at stake. This collection raises these kinds of questions as it begins to address a relative lacuna in work on how these kinds of colonial-era laws may be used to problematize one another. At the same time, this collection goes beyond the law by examining extrajudicial means, including targeted killings, that states throughout South Asia use to silence their critics.

10 Several authors in this collection discuss how India and Bangladesh implement their colonial-era anti-sedition law, often as a means of proving a citizen's affective loyalty to a conflated notion of the nation and the state. In Sri Lanka and Pakistan, we are not following "sedition" inasmuch as we are tracking the career of the Family Background Report in Sri Lanka, and the status of gender variance in relation to national belonging in Pakistan. Rather than showing that all of contemporary South Asia is comparable or in strict juridical alignment, these papers read alongside one another ask what 
meaning discourses and rubrics of feminism, gender-queerness and queer sexuality can make for understanding the production of nationalism at a time when the foil of "antinationalism" is so critically present.

11 The full sweep of the Indian state's concerns about protest and criticism shows that targeting activists as "anti-nationals" in India is taking place under the twinned signs of privatized extractive capitalism and Hindu nationalism. This is evidenced by the ways in which anyone who is not rendered as normatively Hindu, or as being noncompliant with intensified economic stratification, seems to be fair game for arrest and censure. The hand of the state is evident in the pattern of impunity that has taken shape under Hindu nationalist rule, as in the killing of three "rationalist" Indian intellectuals, Narendra Dabholkar in 2013, M.M. Kalburgi and Govind Pansare in 2015, followed by the 2017 murder of journalist Gauri Lankesh in Bangalore. In the context of an English language academic journal, it may be helpful to note that all four of these writers had large audiences for their work in Marathi and Kannada, one ostensible reason why they were seen as a danger to the currently ascendant nationalist project in India.

12 To be sure, there are similar examples of activists being threatened with arrest, violence, and murder in Sri Lanka, Pakistan and Bangladesh. We may recall, for example, the 2015 murder of activist Sabeen Mahmud, gunned down in her car while driving home from a talk she had organized at her cafe in Karachi on the nationalist movement in Balochistan. Regarding responsibility for the attack, "police officers responding to the scene described it as a "targeted' or 'seemingly targeted' killing" (Parshley 2015). In Bangladesh, extrajudicial detention of activists, journalists and intellectuals included photojournalist Shahidul Alam, who was held for 107 days before finally being released on bail in November 2018 (Daily Star 2018). Alam was arrested after giving a statement to the press supporting student protests for road safety in Dhaka, in the wake of a hit and run accident that left two students dead (Tipu, Rabbi, and Chaity 2017). Where the government is not directly involved in ordering or abetting arrests and detention, there seems to be synergy, at least, with other actors who may act with impunity, as evidenced in the spate of machete attacks on bloggers, religious minorities and activists in Bangladesh in 2016 (Khan and Bengali 2016). Dina Siddiqi's article in this volume discusses the murder, during this time, of Xulhaz Mannan, a Dhaka-based activist and blogger who wrote on LGBTQ rights. Sri Lanka's government also struggles to sustain spaces for dissent in the aftermath of its more than 30-year long civil war, which officially ended in 2009, with thousands of Tamils who surrendered to government forces in the last months of the war still missing, and information about them "unavailable." Amnesty International has now formally asked the Sri Lankan government to provide information on the missing and disappeared to their families (Daily Mirror 2018). This request is contextualized by Sri Lanka's postwar "national reconciliation" policy, and the infrastructure granted to this policy by the Office of National Unity and Reconciliation, both of which are intended to create space for religious, linguistic and ethnic minorities in the country. To be sure, these efforts have been fraught (Thiranagama 2013; Vanhullebusch, and Pushparajah 2016).

In light of the array of events I have mentioned here, it would be fair to ask what relation are these papers proposing, in order to link these examples of state impunity, amongst these four different national contexts? While a comparative frame is certainly warranted with respect to the countries that comprise South Asia, the Cold War legacy 
of this mode of regionalization notwithstanding, this collection seeks to highlight struggles over the place of dissent and minority rights in each national political milieu. As such, this collection does not seek to argue for "South Asia" as the only or best comparative frame for all of these national contexts. Rather, these works collectively emphasize a basic insight of feminist historiography, that contemporary struggles over "nationalism" are also necessarily waged along the axes of gender, sexuality, and gender identity. We are substantively interested in "South Asia" because of the shared legal histories amongst its component national contexts, via the shared legacy of British colonialism, and because, to greater and lesser degrees since independence, feminist and queer movements have crossed borders and vast distances for periods of time, and can therefore be said to have had, at certain moments, a shared regional legacy as well.

\section{Sedition and "anti-nationalism" in colonial India}

14 The previous section's examples provide evidence of a period of heightened foreclosure of critical speech in South Asia. It would be wrong, of course, to presume that this historical period is exceptional in this regard. To clarify this, we must also clarify that "sedition" is akin to, but not the same thing as, "treason." Whereas treason is defined as an "act" or a set of "acts" committed against one's own nation, sedition is a crime of speech that "excites or attempts to excite disaffection towards the State" (Narrain 2011:37). In the Indian Penal Code's ([1860] 2011) iteration of the law against sedition, Section 124A, "disaffection" is referenced in the following textual injunction:

Whoever, by words, either spoken or written, or by signs, or by visible representation, or otherwise, brings or attempts to bring into hatred or contempt, or excites or attempts to excite disaffection towards the government established by law [in India], shall be punished with [imprisonment for life], to which fine may be added, or with imprisonment which may extend to three years, to which fine may be added, or with fine.

Explanation 1-The expression "disaffection" includes disloyalty and all feelings of enmity. (Narrain 2011:37; emphasis added)

When the law against sedition is referenced as a "colonial era" law, this sometimes implies that it has remained unchanged since the Indian Penal Code was drafted in 1860. In this sense, critiques of India's anti-sedition law are resonant with critiques of Section 377 (Gupta 2008; EPW Engage 2018). While the language of Section 377 had been in force in a fairly unaltered form since the $1860 \mathrm{draft}$ of the IPC, Section 124A has been in effect since 1870, apparently due to an error that omitted it from the original IPC draft of 1860 (Donogh 1911; Singh 2018:137; Narrain 2011:33). Rajeev Dhavan's (1987) alternate theory of its initial omission from the IPC, that "the British government wanted to adopt more wide-ranging strategies against the press including initiating systems of registration..." (Narrain 2011:33) is consistent with how both 377 and 124A have been deployed. While Dhavan's (1987) argument references the 10-year gap between the drafting of the IPC in 1860, and the inclusion of 124A in the IPC in 1870, and while the deployment of the law has hardly been consistent since that time, it is clear that both 377 and 124A fall within a range of laws and extrajudicial "policies" that have been used intermittently, unevenly and sometimes collectively, over time, to maintain a certain normative order. Section 377, for example, functioned in tandem with anti-vagrancy laws, laws against sex work, and laws against kidnapping in order to prohibit "gay sex" in public spaces. Collectively, these laws enabled the harassment and 
extortion of gender non-conforming and transgender people who were trying to access public space. Ganachari describes how Section 124A has historically functioned in a way that resonates with the history of Section 377.

Unable to stem the surging tide of Indian nationalism at the turn of the nineteenth and the early decades of the twentieth century, the British Indian Government sought to contain "sedition," on the one hand, by a wholesale prosecution of newspapers ... by ever-widening the legal scope of the term "sedition" and also by inventing legal traditions by amending the Indian Penal Code (IPC) and Criminal Procedure Code (Cr. PC); applying different existing laws and enacting new cognate laws such as the Sea Customs Act (1878) the Seditious Meetings Act (1908), and the Indian Press Act (1910) to name a few; to bring those newspapers' editors and printers under the official net. (Ganachari 2009:95)

Tilak and Gandhi, both defendants in two of the most famous sedition trials of the preindependence era, understood that this law was part of a broader legal arsenal used for controlling speech in the press and in the public sphere. This kind of control over forms of speech as part of a discourse that pitted "nationalists" against "antinationalists" was an aspect of the law against sedition that early Indian "nationalists" also understood only too well. Of sedition charge, Gandhi famously wrote:

I consider it a privilege, therefore, to be charged under that section. I have endeavoured to give in their briefest outline the reasons for my disaffection. I have no personal ill-will against any single administrator, much less can I have any disaffection towards the King's person. But I hold it a virtue to be disaffected towards a government which in its totality has done more harm to India than any previous system. India is less manly under the British rule than she ever was before. Holding such a belief, I consider it to be a sin to have affection for the system. And it has been a precious privilege for me to be able to write what I have in the various articles tendered in evidence against me. (Gandhi 1922:168)

Here, Gandhi makes a distinction between being against the government-called rajdroha in Hindi-and being against, or critical of, the people of the countrydeshdroha-where, to be sure, the people are the desh (nation), not the government. This question comes up repeatedly in pre-independence sedition charges and trials, including those of Lokmanya B. G. Tilak, who, like Gandhi, argued that he was against colonial rule as vested in the government-that he was, if anything, rajdroha-but that he was emphatically not deshdroha (Ganachari 2009:95).

Understanding the systematic and dangerous conflation of rajdroha and deshdroha is key to understanding both the history of the discourse of "sedition" in South Asia and how it manifests in contemporary politics. This conflation was apparent during the Emergency in India, from 1975-77, when, following on a disputed national election, Indira Gandhi declared martial law, imprisoned and threatened opposition leaders and those critical of her government, and enforced compulsory sterilization among those segments of the national population that had little or no power to resist (Tarlo 2003; Bhushan 2018). The conflation of being rajdroha and deshdroha has also been apparent in more recent memory, as in the contemporary examples mentioned above, when "sedition" and sedition-like charges have been used to silence dissent and criticism. One of the better known of these instances in the recent past occurred in 2010, when Binayak Sen, a physician working in the state of Chhattisgarh, was actually charged, tried and sentenced to prison for sedition (Vaid 2011), and when, in a separate incident that year, Arundhati Roy was formally accused of sedition, although she was never arrested or formally charged. At that time, a police First Information Report (FIR) was lodged against Roy and Kashmiri separatist leader Syed Ali Shah Geelani, for a speech 
they gave in New Delhi (PTI 2010). The speech was impugned as "seditious" because Roy claimed that Kashmir, a disputed state bifurcated by a "Line of Control" which marks Indian and Pakistani authority, is not an "integral" part of India, a statement that was taken to mean Roy was publically endorsing the secessionist movement in Kashmir. Roy, for her part, characterized her comments thusly:

I spoke about justice for the people of Kashmir who live under one of the most brutal military occupations in the world; for Kashmiri Pandits who live out the tragedy of having been driven out of their homeland; for Dalit soldiers killed in Kashmir whose graves I visited on garbage heaps in their villages in Cuddalore; for the Indian poor who pay the price of this occupation in material ways and who are now learning to live in the terror of what is becoming a police state. (Chamberlain 2010)

There are further resonances between Roy's experience and that of JNU Professor Nivedita Menon, who, in early 2016, was also charged via a formal police complaint over a misrepresentation of her remarks during a speech she had made after the crackdown against speech at JNU had begun. Defending the students' right to raise the issue of Kashmir in their protest, her remarks, delivered in Hindi and recorded on video, were distorted via selective editing and misreporting in order to impute similar designs to those that had been used to target Roy.

It is significant that the state's hackles against "anti-nationals" are raised around particular sets of issues, not the least of which is the constitution of the nation's territoriality. Certain questions-of, for example, Kashmiri and Balochi nationalism, of the displacement of entire villages in Chhattisgarh in the face of multinational mining projects (WSS 2017), of the consolidation of Dalit and tribal franchise in Maharashtra (Parmar 2018), of environmental degradation and destruction in the wake of copper production in Tamil Nadu (Scroll Staff 2018b), protests against road safety (and bad governance by proxy) in Dhaka (Safi 2018a)-have drawn the full force of state repression in India Pakistan and Bangladesh, including not only the use of the law against sedition, but also the array of anti-terrorism and public nuisance laws. We may derive at least two insights from this very truncated representation of sedition and "anti-nationalism" discourses in South Asia. First, that sedition is embedded within a wider discourse on the constitution of the nation, where stateist anxieties regarding certain forms of speech evince the fragility of the idea of "national unity," especially when the state responds to certain speech acts with organized violence. Second, given that "anti-nationalism" embodies such a far-reaching discursive rubric, understanding how and where it functions demands an equally expansive analytic rubric; this volume suggests that this rubric must include questions of gender, sexuality and gender identity as well.

\section{'Queer and trans* feminism' in South Asia}

The persistence and uses of the law against sedition throughout South Asia are as much an instigation for this volume as are the wider discursive slippages between "rajdroha" and "deshdroha." of equal importance is the long tradition of South Asian feminist critiques of nationalism, and the significant shifts in how sexuality and gender identity have been differently legible at different points in time, with respect to the rhetoric of nationalism in South Asia. In referencing feminist critiques of nationalism, many of the authors here reference postcolonial feminist critiques of gender in relation to the 
formation of South Asian nation states during the era of anti-colonial struggle (Jayawardena [1986] 2016; Sinha 1995; Chatterjee 1990), the longstanding insight that there are no seamless or a priori connections between nation, religion, territory, and the state in South Asia (Jalal 2000), and the continued importance of women's movements throughout South Asia in constantly interrogating citizenship and state power (Basu 2016; Roy 2013; Loomba and Lukose 2012).

Historically, these kinds of critiques focused on asking what the category of "women" meant to anti-colonial struggles and in the aftermath of independence (Menon and Bhasin 1998; Jayawardena [1986] 2016). In this way, postcolonial feminist scholarship in South Asia has long facilitated asking how gender and sexuality become the bases for national/ethnic/cultural belonging and un-belonging, and whether individual cisgender "women" are even legible as subjects in their own right (Sunder Rajan 1993). In India, this question is necessarily mobilized in its contemporary context in relation to critiques of Hindu nationalist ideology and the ways in which normative tropes of masculinity (Sinha 1995; Shah 2002; Banerjee 2005), for example, have been integral to its formation. A few key nodes of scholarship in this vein clarify certain attachments between questions of gender, sexuality and national belonging. These include earlier debates on "age of consent" legislation (Sinha 1995; Sarkar 2000), interrogating the notion of the private sphere and private space (Grewal 1996:25), more recent debates in India on how to challenge the terms of "personal law" from a feminist perspective (Menon 1998; Naqvi 2017), and on the ways in which caste has long framed the terms of national belonging, writ large (Rege 2000; Chakravarti 2000; Paik 2014). ${ }^{8}$

In queer and trans studies in the Western academy, there is an emerging rearticulation of interest in questions of nationalism, thanks to the rise of troubling and not necessarily predictable alignments between sexuality, gender identity and the nation state. "Pinkwashing" is one of the more circulated examples of how queerness and right-wing nationalism, for example, are aligned (Puar 2017). Some of this interest is manifest in critiques of sexuality politics that are part of the "decolonial" turn in queer studies (Bakshi, Suhraiya, and Posocco 2016; Darwich and Maikey 2014) and in trans studies (Aizura et. al. 2014). In South Asian Studies, critiques of the relationships between sedition, anti/nationalism, gender identity and sexuality have similarly been manifest as an exercise in which "suppression" is productive of much more than simple erasure. In this regard, Raminder Kaur and William Mazzarella write, "Why and when did specific markers of excess such as 'obscenity,' 'sedition,' and 'blasphemy' come into play in projects of cultural regulation, and what can we learn from their shifting interrelationships?" (Kaur and Mazzarella 2009:13). Identifying their project as "comparative" across South Asia, Mazzarella and Kaur's volume discusses a number of instances wherein questions of sexuality are tied to "cultural regulation" and maintaining social order. These include accusations of blasphemy in Pakistan (Ahmed 2009), and the ways in which "Bangladesh emerged onto the international map of censorship when Taslima Nasreen's novel Lajja was banned in 1993" (Kaur and Mazzarella 2009:2).

Speaking in a similar mode of the suppression of "Dalit sexualities" in late nineteenthcentury colonial India, Charu Gupta writes, "Disciplinary power was not necessarily suppressive but was also productive of new expressions of sexuality" (Gupta 2011:16). In linking the implicit and explicit Brahminism of the "Indian" state in the decades immediately following the 1857 uprising with nationalist anxieties in representing the 
Indian polity as sufficiently modern and "qualified" for self-rule, Gupta explains how suppressing marginalized sexualities was productive of an emergent nationalist attachment to normative heterosexuality:

While the British criminalized same-sex love by the 1861 law, Indian reformersboth revivalists and nationalists-were attempting to regulate homosex by insisting that it was alien to Indian culture. In addition, they were trying to render conjugality the space of both procreation and pleasure. Monogamous, heterosexual, and companionable marriage was envisaged as imperative for a modern, civilized, Hindu nation. Female reproduction was linked to its utility to the nation, as it was seen as leading to the enhancement of a healthy, male progeny. In such a scenario, perceived Dalit sexualities too were constructed as deviant, and a threat to "civilized" norms of sexual behavior. (Gupta 2011:14)

This body of work has evinced a generalized critique that discourses of gender and sexuality in South Asia must also be understood in relation to the formation of ideals of national progress. This critique is present in Lata Mani's foundational work, for example, on the "invented tradition" of sati and its official banning in 1829 through a combination of efforts by Hindu reformists like Raja Ram Mohan Roy and British administrators (Mani 1990). It is also present in Nivedita Menon's introduction to her edited anthology Sexualities, where she writes,

Technologies of surveillance and laws of prohibition are indeed central to understanding sexuality, and determine what will be termed as sexuality at all. But it is also imperative to note that such forms of control and hygiene, including the "cleaning up" of uncontrollable forms of sexuality, come with modernity and the values that accompany it-progress, the inevitability of historical forms, the language of rights. (Menon 2007a:xv)

Feminist scholarship is rife with these themes on sexuality in India by the late 1990s, when anthologies like A Question of Silence (Nair and John 1998) were being read alongside published reports on queer and trans existence, including Humjinsi: A Resource Book on Lesbian, Gay and Bisexual Rights in India (Fernandez 2002) and work on the Hindu right's organized backlash against the lesbian-themed film Fire in 1996 (John and Niranjana 2000). They are also widespread in the trove of critical work inspired and authored by autonomous feminism and lesbian/bisexual/trans organizing (Shah et. al. 2015), and the campaign to decriminalize homosexuality in India (Narrain and Bhan 2005; Bhattacharyya and Bose 2007), which took shape around juridical questions, to be sure, while asking what legal recognition and its lack mean for a group of people who are seen to be demanding categorical minority rights. Furthermore, what did this kind of recognition mean for other modes of minoritization, as tied to religion, or caste?

This particular collection of articles draws its legibility through the bodies of work I reference above, and through an understanding that the rise in judicial and extrajudicial means of suppressing speech and managing dissent is productive of radical thinking and politics inasmuch as it represses and erases. The forms of dissent that generated the impetus for the symposium from which this collection is derived are fundamentally tied to questions of autochthonous sovereignty. These forms of dissent have produced especially violent instances of backlash coming from the state when they are tied to questions of land use and demands for autonomous governance. A number of the discursive sites I mention above-Balochi and Kashmiri nationalism, appropriating land for mines, and other large-scale development projects in Indiainvolve unresolved questions about the power of the state. In India, these sites of 
confrontation have historically involved the ways in which laws like the Armed Services Special Powers Act (AFSPA), the Maintenance of Internal Security Act (MISA), and the Prevention of Terrorism Act (POTA) have all been used to suspend democratic rights in regions where the state determines that security is especially at risk. These have become sites of massive, documented abuses of state power (Singh 2007). In Bangladesh, the recently passed Information and Communications Technology Act serves a similar function, eliciting condemnations from the International Commission of Jurists (International Commission of Jurists 2013,) and Human Rights Watch (Bergman 2018). How these kinds of laws function in South Asia is perhaps clearest in Bangladesh, where neoliberal economic reforms were enacted fairly early, and where the impacts of structural adjustment programs and privatizing national assets has contributed to extreme economic stratification and a vastly expanded informal economy (Muhammad 2015). With so much at stake for corporate and political elites, any articulation of dissent or critiques that would be perceived as threats to privatized surplus wealth would be dealt with as such.

The innovation of this collection is in making space for reading questions of gender and sexuality against this backdrop of anti-democratic laws and practices that have acquired additional potency in recent years; many of these laws and practices facilitate the consolidation of wealth through resource extraction on an unprecedented scale. At the same time, these works evince an interest in an analytic experiment: what would happen if we could account for the history of feminist critiques of nationalism alongside newer modes of queer and trans politics? These two aspects of this curation of papers enable us to collectively ask what queerness, gender variance and feminism mean to political radicalism, particularly in a moment which seems to be dominated by rightwing populism (Mazzarella 2018). Furthermore, what do questions of sexuality and gender identity have to do with revolutionary politics, with questions of class and political economy? How and where are the spaces for radical critique constituted when the stakes of dissent and radical struggle seem to be climbing ever higher? Does it mean something to have a queer feminist analysis, or to be queer or trans in antidemocratic times? The short answer is, yes, of course, but these meanings are multiple, and the grounds on which the politics of sexuality and gender rest are highly contested. Drawing on the longstanding history of feminist engagements with and reliance upon the notion of dissent, and on work that interrogates the intersections of gender identity, sexuality and national belonging, this collection seeks to show how these kinds of critiques complicate the ways in which accusations of "national" and "anti-national" are wielded, and to what effect.

\section{The papers}

24 These works collectively examine discourses of "anti-nationalism" and attendant laws, in relation to the mutually imbricated categories of trans, queer, and feminist politics in South Asia. Given that the crackdown on student activism relating to Kashmir at JNU served as the initial impetus for the conference from which these papers are drawn, a number of them, by Khubchandani, Dutta, Bhattacharya, and Shahani, deal specifically with queer, trans and feminist politics in relation to the spaces of student activism and politics in India, where accusations of "anti-nationalism" have been deployed by the state and proxy organizations. Jegathesan draws on attendant questions of dissent to 
reexamine feminist critiques of nationalism and the state in relation to women and "gender" broadly. In this sense, we may read Jegathesan's contribution, which deals with the status of cisgender women within instantiations of right-wing nationalism, alongside the articles by Khan, Bhattacharya and Dutta, which all address the question of nationalism in relation to the legibility of trans people and politics in South Asia. Taken together, these works take up longstanding questions within South_Asian feminisms on the constitutive importance of gender for the idea of the nation "itself." Extending these critiques, some authors in this volume also ask: if trans people and politics are now visible within various projects of both left and right wing South Asian nationalisms, then what does this visibility, and legibility, tell us about the constitution of the nation within the changing geopolitics of gender and sexuality?

Faris Khan's contribution takes up this question by considering the ways in which gender nonconforming khwaja siras, people assigned male sex at birth whose gender comportment is feminine, negotiate activism in such a way as to avoid accusations of "anti-nationalism" in Pakistan, while at the same time "complicat[ing] notions of dissent through engagement in indigenous modes of resistance" (Khan, this volume). Khan's paper considers the rubric of minority rights in Pakistan, the ways in which it has elicited accusations of anti-nationalism, and how khwaja sira activists negotiate a space which at once renders them legible to the state as equal citizens, while also relegating khwaja siras to the status of a "partially legible," ethnicized minority.

Sayan Bhattacharya's piece also examines the newfound juridical legibility of hijra and other trans-identified subjects-this time in India-as evidenced by the existence of transgender development boards in different Indian states, and the controversial Transgender Persons (Protection of Rights) Bill, 2018. While much commentary has been generated on so-called hijra nationalism in India, where hijra activists have intentionally taken on and promoted Hindu nationalist ideology, less has been said about how hijras, transgender and gender nonconforming people have disrupted any nationalist framing of their lives using not only varied modes of protests but also varied gender embodiments (Bhattacharya, this volume).

Also dealing with questions elicited by trans-feminine politics, Aniruddha Dutta's piece examines the relationships between student organizing and trans-queer activism in Eastern India. Dutta points out that, during the national protests that followed the rape and murder of Jyoti Singh Pandey in Delhi in 2012 (usually referenced as "the Delhi rape case"), protests in West Bengal included trans-feminine communities, include kothi and hijra communities, who "used these protests as a platform to highlight gendered/sexual violence against trans-queer people ... [at the same time] and some student activist outfits also included anti-trans violence in their agendas." Dutta describes a number of trans-student-queer alliances over the past several years that mark a "watershed" in queer and trans activism in the region. The piece considers the ways in which these alliances are also sites of "productive tensions across variant conceptualizations of dissent and resistance to capital and the nation-state" (Dutta, this volume).

28 A number of pieces in this volume deal with the killing or suicide of activists and individuals whose very being is construed as an existential threat to the constitution of the nation. In her piece "Hierarchies of Suffering, Seditious Sexualities and Unmournable Bodies," Dina Siddiqi discusses the 2016 murder of gay rights activist and blogger Xulhaz Mannan within the context of an extremely delimited and shrinking 
space for expressing political and "cultural" dissent in Bangladesh. Siddiqi considers why information about certain murders circulates internationally, such as the 2016 murder, while other equally horrific instances of violence and killing does not. In pointing to this disjuncture, Siddiqi asks how the fetishization of LGBTQ bodies contributes to certain erasures, to the effacement of non-fetishized "bodies" who are also targeted by the state and its proxies. Given that "[t]o the government, both queer and politically dissident bodies are disposable ... [Siddiqi explores] how we might think of dissident politics in the context of 'seditious' sexualities within the current political climate in Bangladesh..." (Siddiqi, this volume).

In this vein, a number of pieces invoke the student uprisings at the University of Hyderabad during 2016, in the wake of Rohith Vemula's suicide. Nishant Shahani's piece considers two "institutional murders" in India, Vemula's and that of Professor Ramchandra Siras, who was caught having consensual sex with another man by two men who broke into his home in 2010. Professor Siras, a linguist who had taught for more than two decades at Aligarh Muslim University, was found dead in his apartment some months later. Although initially thought to be a suicide, police later treated it as a case of murder. Shahani discusses these two cases of "institutional murder" in order to ask: "what does it mean to argue for queer national belonging through jurisprudence at the very historical moment in India when the rhetoric of sedition and compulsory nationalism is mobilized as a way to violently erase dissent?" (Shahani, this volume).

Kareem Khubchandani's piece traverses multiple geographic terrains, following the subject of Khubchandani's interview, Moses Tulasi, from Hyderabad to Chicago and back again. Khubchandani tells Tulasi's story as a member of a South Asian LGBTQ organization in Chicago for many years, and as someone with deep family connections in Hyderabad. Tulasi becomes involved in the student protests at the University of Hyderabad, is eventually arrested while filming there, and accused of "un-Indian" activity. The interview traces Tulasi's analysis through his own subject position as "a diasporic, queer, OBC (other backward caste) filmmaker" who offers "anecdotes and theorizations about how queerness, migration, and caste matter to each other. These 'entanglements,' material imbrications and discursive confluences, offer new facets to the study of sedition in India by centering an unlikely and even accidental protagonist..." (Khubchandani, this volume).

31 A number of works presented during the symposium in 2016 were written in the tradition of South Asian feminist critiques of the idea of cisgender women in relation to the idea of the nation. These works were presented within a contemporary critique that was both queer and feminist, and, like the rest of the articles here, these works were also informed by the histories of both queer and feminist theory. Of the three such pieces presented at the 2016 symposium one is included here, Mythri Jegathesan's article, "Discomforting the State: Narratives of Women's Labor, Reproductive Capacity and Sexuality in Postwar Sri Lanka." It considers three ethnographic moments from the author's fieldwork that illustrate the complexities of Tamil and Muslim minoritization among women and girls working as manual laborers within and from Sri Lanka. These three moments-two of murder, and one of tubal ligation done under the auspices of a national family planning initiative-give Jegathesan the opportunity to examine "how representations of women's reproductive capacity, sexuality, and choice were deployed as potential threats or affirmations to the Sri Lankan state, its economic standing at industrial levels, and its cohesion as a postwar majoritarian nation" (Jegathesan, this 
volume). Jegathesan argues that official accounts of minority women's lives and labor are incommensurate with minority women workers' own understandings of their work and bodies. The space between these two modes of representation also constitutes the space for feminist ethnography, in the possibilities the piece explores for displacing official narratives of non-majoritarian women.

The volume ends with an interview between Rohit De and Inderpal Grewal, where De and Grewal offer a historical critique of sedition in India, and its relationship to other kinds of laws in this vein, including anti-blasphemy laws in Pakistan. They discuss how these individual laws are part of a family of regulations targeting speech that is blamed for inciting violence and pubic disorder. They discuss the effect that this family of laws, and the broader discourses of nationalism of which they are a part, ultimately have on speech. In making the links between empire, the regulation of speech, gender, and sexuality, De and Grewal talk about militarized feminism and discourses of protection that sustain patriarchal norms, and how women challenge these norms through unpredictable and at times counterintuitive means. Spanning topics as diverse and closely linked as surveillance, "encounter killings," Aaron Schwartz's suicide, ${ }^{9}$ and the demand for an independent Khalistan, De and Grewal convey the monumentality of these questions in relation to how their history will eventually be told.

\section{Conclusion}

This special issue is ambitious in its scope, aiming to contribute to a scholarly literature that seeks to address the conceptual gaps between the personal and the political, the affective and the juridical, and between governance and sex. If this task is impossible in a single collection, the frames that make these papers legible within the theme I have described are perhaps more easily recognized. What is more challenging is to convey the spirit of the meeting that produced these papers, and the imperative for collecting them in this special issue. What was ultimately at stake during this event, and in this collection, is the question of what happens when national subjects in the region are asked to align their status as citizens with an institution like the military, an ostensibly "charismatic" leader, majoritarian erasure, and/or the "financialization of everything." These are inescapably questions of class, caste, racialization, gender, sexuality and gender identity as well.

In the spirit of these questions and the literatures and critiques they invoke, I close by quoting a poem by gay Delhi-based poet and scholar Akhil Katyal. Katyal ended the 2016 Feminist Preconference with a performance of this piece and, fittingly, it ends this introduction as well. The poem's provenance notes the ways in which gay and feminist activists and writers have long been engaged with questions of policing, speech and democratic rights around the world. If anything, the sequestration of feminist and LGBTQ work to a liberalized notion of gender and sexuality is relatively new, in historical terms, and perhaps already short lived. This collection seeks to expand the terrain on which we may deploy critiques of state-sponsored impunity and the repression of dissent, such that these critiques account for the lives of women, gays, lesbians, transgender people, but, perhaps more fundamentally, such that gender and sexuality are integral to our critiques of authoritarianism in South Asia.

\section{To the Soldier in Siachen}

by Akhil Katyal (2017) 
Come back

the snow is treacherous,

come back

they are making you fight a treacherous war,

you were not born in snow

you do not know snow, come back,

I do not want you to fight that war in our name,

I want you to rest, I want you to be able to feel your fingers,

I want the snow in your veins to give way

for you to be able to breathe, to melt

into a corner, to sleep.

Come back.

Go home.

Go home to Dharwad,

Go home to Madurai, go home

to Vellore, Satara, Mysore,

do not stay in the snow,

go home to Ranchi, that war

is not for you to fight, that war

is not for us to give to you to fight,

let not our name be ice,

let it not heave on your shoulders,

do not let us steal your breath,

the people there, the people of the snow

do not need us, they do not need you to fight,

come back

you were not born to snow,

you do not know the treachery of snow,

go home,

to rest, go home to the sun, to water,

go home to the nights of your village,

go home to the sweltering marketplace,

to the noise of family-homes, to the sweat of the Ghats,

to the dust of the plains, go home,

may you never

have to see white like that ever again,

may you never have to see a colour

become death in your very palm.

\section{BIBLIOGRAPHY}

Ahmed, Asad Ali. 2009. “Specters of Macaulay Blasphemy, the Indian Penal Code, and Pakistan's Postcolonial Predicament." Pp. 172-205 in Censorship in South Asia: Cultural Regulation from Sedition to Seduction, edited by R. Kaur and W Mazzarella. Bloomington: Indiana University Press.

Aizura, Airen, Marcia Ochoa, Salvador Vidal-Ortiz, Trystan Cotton, and Carsten Balzer/Carsten

LaGata. 2014. "Decolonizing the Transgender Imaginary." Special issue of Transgender Studies Quarterly 1(3). 
Bakshi, Sandeep, Jivraj Suhraiya, and Sylvia Posocco, eds. 2016. Decolonizing Sexualities: Transnational Perspectives, Critical Interventions. Oxford: Counterpress.

Banerjee, Sikata. 2005. Make Me a Man!: Masculinity, Hinduism, and Nationalism in India. Albany: SUNY Press.

Basu, Amrita. 2016. Women's Movements in the Global Era: The Power of Local Feminisms. $2^{\text {nd }}$ ed. New York: Routledge.

Bergman, David. 2018. No Place for Criticism: Bangladesh Crackdown on Social Media Commentary. Human Rights Watch. New York: Human Rights Watch. Retrieved February 13, 2019 (https:// www.hrw.org/report/2018/05/09/no-place-criticism/bangladesh-crackdown-social-mediacommentary).

Bhattacharyya, Subhabrata and Brinda Bose. 2007. The Phobic and the Erotic: The Politics of Sexualities in Contemporary India. Calcutta: Seagull Books.

Bhushan, Prashant. 2018. The Case that Shook India: The Verdict that Led to the Emergency. New Delhi: Penguin India.

Butler, Judith. 2004. Precarious Life: The Powers of Mourning and of Violence. London: Verso.

Chakravarti, Uma. 2000. Rewriting History: Life and Times of Pandita Ramabai. Delhi: Kali for Women. Chatterjee, Partha. 1990. “The Nationalist Resolution of the Women's Question.” Pp. 233-53 in Recasting Women: Essays on Colonial History, edited by K. Sangari and S. Vaid. New Delhi: Zubaan Books.

Darwich, Lynn, and Haneen Maikey. 2014. "The Road from Antipinkwashing Activism to the Decolonization of Palestine.” Women's Studies Quarterly 42(3-4):281-85.

Dhavan, Rajeev. 1987. Only the Good News: On the Law of the Press in India. New Delhi: Manohar Publications.

Donogh, Walter Russell. 1911. A Treatise on the Law of Sedition and Cognate Offences in British India. Calcutta: Thakker, Spink and Co.

EPW Engage. 2018. "How Has 'Progressive' Thought about Homosexuality Evolved since the 1990s?” Economic and Political Weekly, January 24. Retrieved February 13, 2019 (http:// www.epw.in/engage/article/how-has-\%E2\%80\%9Cprogressive\%E2\%80\%9D-thought-abouthomosexuality-evolved-1990s).

Fernandez, Bina, ed. 2002. Humjinsi: A Resource Book on Lesbian, Gay, and Bisexual Rights in India. Mumbai: India Centre for Human Rights and Law.

Ganachari, Aravind. 2009. "Combating Terror of Law in Colonial India: The Law of Sedition and the Nationalist Response." Pp. 93-110 in Engaging Terror: A Critical and Interdisciplinary Approach, edited by M. Vardalos, G. K. Letts, H. M. Teixeira, A. Karzai, and J. Haig. Boca Raton: Brown Walker Press.

Gandhi, Mohandas Karamchand. 1922. “The Great Trial.” Young India 4(12):165-71. Retrieved February 13, 2019 (http://dart.columbia.edu/library/DART-0030/DART-0030.html? context=main).

Ghosh, Nandini and Suparna Banerjee, eds. 2018. "Caste-Gender Intersections in Contemporary India." Special issue of SAMAJ: South Asia Multidisciplinary Academic Journal 19. Retrieved February 13, 2019 (https://journals.openedition.org/samaj/4574). 
Grewal, Inderpal. 1996. Home and Harem: Gender, Empire and Cultures of Travel. Durham: Duke University Press.

Gupta, Alok. 2008. This Alien Legacy: The Origins of "Sodomy" Laws in British Colonialism. Human Rights Watch. New York: Human Rights Watch. Retrieved February 13, 2019 (https:// www.hrw.org/report/2008/12/17/alien-legacy/origins-sodomy-laws-british-colonialism). Gupta, Charu. 2011. "Writing Sex and Sexuality: Archives of Colonial North India." Journal of Women's History 23(4):12-35.

India. [1860] 2011. Indian Penal Code. Lucknow: Eastern Book Company.

Indian Penal Code. 1860. Section 377 in the Indian Penal Code, "Unnatural Offences." Retrieved April 16, 2019 (https://indiankanoon.org/doc/1836974/).

Indian Penal Code. 1860. Section 124A in the Indian Penal Code, "Sedition." Retrieved April 16, 2019 (https://indiankanoon.org/doc/1641007/).

Jalal, Ayesha. 2000. “South Asian Nationalism.” Pp. 737-56 in The Encyclopedia of Nationalism: Fundamental Themes. Vol. 1, edited by A. Motyl. San Diego: Academic Press.

Jayawardena, Kumari. [1986] 2016. Feminism and Nationalism in the Third World. London: Verso. JNUTA (JNU Teachers' Association). 2017. What the Nation Needs to Know: The JNU Nationalism Lectures. Delhi: Harper Collins India.

John, Mary, and Tejaswini Niranjana. 2000. "Mirror Politics: Fire, Hindutva and Indian Culture." Inter-Asia Cultural Studies 1(2):374-79.

Katyal, Akhil. 2017. “To the Soldier in Siachen.” Plume Poetry. Retrieved February 13, 2019 (http:// plumepoetry.com/2017/10/featured-selection-22-contemporary-indian-poets/\#Siachen).

Kaur, Raminder, and William Mazzarella, eds. 2009. Censorship in South Asia: Cultural Regulation from Sedition to Seduction. Bloomington: Indiana University Press.

Loomba, Ania, and Ritty Lukose. 2012. South Asian Feminisms. Durham: Duke University Press.

Mani, Lata. 1990. “Contentious Traditions: The Debate on Sati in Colonial India." Pp. 88-126 in Recasting Women: Essays on Colonial History, edited by K. Sangari, and S. Vaid. New Delhi: Zubaan Books.

Mazzarella, William. 2018. "The Anthropology of Populism: Beyond the Liberal Settlement [drafted_for_Annual_Review_of_Anthropology 2019].” Retrieved February 13, 2019 (http:// www.academia.edu/38026877/

The_Anthropology_of_Populism_Beyond_the_Liberal_Settlement_drafted_for_Annual_Review_of_Anthropology).

Menon, Nivedita. 1998. "State/Gender/Community: Citizenship in Contemporary India." Economic and Political Weekly 33(5):PE3-PE10.

Menon, Nivedita. 2007a. "Introduction." Pp. xiii-lx in Sexualities, edited by N. Menon. New Delhi: Women Unlimited, Kali for Women.

Menon, Nivedita, ed. 2007b. Sexualities. New Delhi: Women Unlimited.

Menon, Ritu, and Kamala Bhasin. 1998. Borders and Boundaries: How Women Experienced the Partition of India. New Delhi: Kali for Women.

Mukhopadhyay, Maitrayee. 2015. "Gendered Citizenship in the Postcolony: The Challenge for Transnational Feminist Politics.” Pp. 607-25, in The Oxford Handbook of Transnational Feminist Movements, edited by R. Baksh and W. Harcourt. Oxford: Oxford University Press. 
Muhammad, Anu. 2015. "Bangladesh-A Model of Neoliberalism: The Case of Microfinance and NGOs.” Monthly Review 66(10). Retrieved February 13, 2019 (https://monthlyreview.org/ 2015/03/01/bangladesh-a-model-of-neoliberalism/).

Nair, Janaki, and Mary John, eds. 1998. A Question of Silence: The Sexual Economies of Modern India. New Delhi: Kali for Women.

Naqvi, Farah. 2017. Working with Muslims: Beyond Burqa and Triple Talaq. Stories of Development and Everyday Citizenship in India. New Delhi: Three Essays Collective.

Narrain, Arvind, ed. 2018. Right to Love: Navtej Singh Johar v. Union of India: A Transformative Constitution and the Rights of LGBT Persons. Bangalore: Alternative Law Forum. Retrieved February 13, 2019 (http://altlawforum.org/wp-content/uploads/2018/09/RightToLove_PDFVersion-1.pdf).

Narrain, Arvind and Gautam Bhan, eds. 2005. Because I Have a Voice: Queer Politics in India. New Delhi: Yoda Press.

Narrain, Siddharth. 2011. "'Disaffection' and the Law: The Chilling Effect of Sedition Laws in India." Economic and Political Weekly 46(8):33-37.

Paik, Shailaja. 2014. Dalit Women's Education in Modern India: Double Discrimination. New York: Routledge Press.

Puar, Jasbir. 2017. Terrorist Assemblages: Homonationalism in Queer Times. Durham: Duke University Press.

Rege, Sharmila. 2000. "'Real Feminism' and Dalit Women: Scripts of Denial and Accusation." Economic and Political Weekly 35(6):492-95.

Roy, Srila. 2013. New South Asian Feminisms: Paradoxes and Possibilities. London: Zed Books.

Shah, Chayanika, Raj Merchant, Shals Mahajan, and Smriti Nevatia. 2015. No Outlaws in the Gender Universe. New Delhi: Zubaan Books.

Shah, Ghanshyam. 2002. "Caste, Hindutva and Hideousness." Economic and Political Weekly 37(15): 1391-93.

Sharafi, Mitra. 2015. "South Asian Legal History.” Annual Review of Law and Social Science 11:309_ 36.

Singh, Anushka. 2018. Sedition in Liberal Democracies. New Delhi: Oxford University Press.

Singh, Ujjwal Kumar. 2007. The State, Democracy and Anti-Terror Laws in India. New Delhi: Sage Publications.

Sinha, Mrinalini. 1995. Colonial Masculinity: The "Manly Englishman" and the "Effeminate Bengali" in the Late Nineteenth Century. Manchester: Manchester University Press.

Sarkar, Tanika. 2000. “A Prehistory of Rights: The Age of Consent Debate in Colonial Bengal." Feminist Studies 26(3):601-22.

Sukumar, Narayana. 2016. “'Red Sun in the Blue Sky': Rohith Vemula's Utopian Republic.” Social Change 46(3):451-57.

Sunder Rajan, R. 1993. Real and Imagined Women: Gender, Culture and Postcolonialism. London: Routledge.

Tarlo, Emma. 2003. Unsettling Memories: Narratives of the Emergency in Delhi, New Delhi: Permanent Black. 
Thiranagama, Sharika. 2013. "Claiming the State: Postwar Reconciliation in Sri Lanka." Humanity: An International Journal of Human Rights, Humanitarianism, and Development 4(1):93-116.

Vaid, M. 2011. A Doctor to Defend: The Binayak Sen Story. New Delhi: Rajpal and Sons.

Vanhullebusch, Matthias, and Nadarajah Pushparajah. 2016. "The Politics of Prosecution of International Crimes in Sri Lanka." Journal of International Criminal Justice 14(5):1235-60.

Warner, Michael. 2000. The Trouble with Normal: Sex, Politics and the Ethics of Queer Life. Cambridge: Harvard University Press.

Wiegman, Robin. 2012. Object Lessons. Durham: Duke University Press.

WSS (Women Against Sexual Violence and State Repression). 2017. Bearing Witness: Sexual Violence in South Chhattisgarh. Bhopal: WSS. Retrieved February 13, 2019 (https://wssnet.org/category/ publications/).

Zia, Ather. 2018. “The Killable Kashmiri Body: The Life and Death of Afzal Guru.” Pp. 103-28 in Resisting Occupation in Kashmir, edited by H. Duschinski, M. Bhan, A. Zia, and C. Mahmood. Philadelphia: University of Pennsylvania Press.

\section{Newspaper articles and press releases}

Chamberlain, Gethin. 2010. "Arundhati Roy Faces Arrest over Kashmir Remark." The Guardian, October 26. Retrieved February 13, 2019 (https://www.theguardian.com/world/2010/oct/26/ arundhati-roy-kashmir-india).

Daily Mirror. 2018. “AI Urges SL to Release Lists of Forcibly Disappeared.” Daily Mirror, May 18. Retrieved February 13, 2019 (http://www.dailymirror.lk/article/AI-urges-SL-to-release-lists-offorcibly-disappeared-150108.html).

Daily Star. 2018. "Freedom at Last." Daily Star, November 21. Retrieved February 13, 2019 (https://www.thedailystar.net/city/photographer-shahidul-alam-walks-out-jail-1663237).

Express Web Desk. 2019. "BHU Violence: Had Inputs that 'Anti-social' Elements Will Try to Vitiate University's Atmosphere, Says VC Girish Tripathi.” Indian Express, March 16. Retrieved March 15, 2019 (https://indianexpress.com/article/india/bhu-violence-we-had-information-that-antisocial-elements-will-disturb-university-environment-says-bhu-vc-4858921/).

Farooq, Omer. 2016. "Rohith Vemula: The Student Who Died for Dalit Rights." BBC News, January 19. Retrieved February 13, 2019 (http://www.bbc.com/news/world-asia-india-35349790).

Grover, Anand. 2015. "Viewpoint: Why India Was Wrong to Hang Yakub Memon.” BBC, August 6. Retrieved February 13, 2019 (http://www.bbc.com/news/world-asia-india-33772144).

International Commission of Jurists. 2013. "Bangladesh: Information and Communication Technology Act Draconian Assault on Free Expression." November 30. Retrieved February 13, 2019 (https://www.icj.org/bangladesh-information-and-communication-technology-actdraconian-assault-on-free-expression/).

Johari, Aarefa, Abhishek Dey, Mridula Chari, and Shone Satheesh. 2018. "From Pune to Paris: How a Police Investigation Turned a Dalit Meeting into a Maoist Plot." Scroll.in, September 2. Retrieved February 13, 2019 (https://scroll.in/article/892850/from-pune-to-paris-how-a-policeinvestigation-turned-a-dalit-meeting-into-a-maoist-plot?utm_source=alsoread).

Khan, Mainul Islam, and Shashank Bengali. 2016. "Bangladesh Crackdown: More Than 14,000 Arrests, yet Machete Attacks Continue.” LA Times, June 16. Retrieved February 13, 2019 (http:// www.latimes.com/world/asia/la-fg-bangladesh-crackdown-20160616-snap-story.html). 
Manral, Mahendra Singh. 2018. "Draft JNU Sedition Chargesheet Names Kanhaiya Kumar, Umar Khalid, Anirban." Indian Express, December 21. Retrieved February 13, 2019 (https://

indianexpress.com/article/india/jnu-sedition-chargesheet-kanhaiya-khalid-anirban-

slogans-5503183/?fbclid=IwAR3m9q-

twemKXzDHnDY2MwYA3UUBOw3tXKtzc2Wo7_itNIk9VA9mnat_sFg).

Pal, Deepanjana. 2015. "Blocked in DU, Documentary 'Muzaffarnagar Baaqi Hai' Is a Must Watch.” Indian Express, August 21. Retrieved February 13, 2019 (https://www.firstpost.com/

entertainment/blocked-in-delhi-university-documentary-muzaffarnagar-baaqi-hai-is-a-mustwatch-2408662.html).

Parmar, Tekendra. 2018. "The Persecution of GN Saibaba and India's 'Annihilation' of the Resistance.” The Nation, May 2. Retrieved February 13, 2019 (https://www.thenation.com/article/ the-persecution-of-gn-saibaba-and-indias-annihilation-of-the-resistance/).

Parshley, Lois. 2015. “The Life and Death of Sabeen Mahmud.” The New Yorker, April 28. Retrieved March 21, 2019 (https://www.newyorker.com/news/news-desk/the-life-and-death-of-sabeenmahmud).

People's Union for Democratic Rights (PUDR). 2016. ““'How Democracy 'Uses’ a Colonial Law”: PUDR's statement on \#JNUCrackdown." India Resists, February 2. Retrieved February 13, 2019 (https://indiaresists.com/how-democracy-uses-a-colonial-law-pudrs-statement-onjnucrackdown/).

PTI (Press Trust of India). 2010. “Geelani, Arundhati to be Booked under Sedition Charge.” Times of India, October 25. Retrieved February 13, 2019 (https://timesofindia.indiatimes.com/india/ Geelani-Arundhati-to-be-booked-under-sedition-charge/articleshow/6810983.cms).

Safi, Michael. 2018a. "Photographer Charged as Police Crackdown in Bangladesh Intensifies." The Guardian, September 6. Retrieved February 13, 2019 (https://www.theguardian.com/world/2018/ aug/06/famed-bangladeshi-photographer-held-over-road-protest-comments).

Safi, M. 2018b. "Campaigners Celebrate as India Cecriminalises Homosexuality." The Guardian, September 6. Retrieved February 13, 2019 (https://www.theguardian.com/world/2018/sep/06/ indian-supreme-court-decriminalises-homosexuality).

Sahni, PS. 2018. “An Open Letter to Indian Parliamentarians to Get Section 377, IPC Repealed in Toto." AIDS BhedBhav Virodhi Andolan (AIDS Anti-Discrimination Movement), October 6. Retrieved February 13, 2019 (http://aidsbhedbhavvirodhiandolan.blogspot.com/2018/10/an-open-letterto-indian.html).

Schwartz, John. 2013. "Internet Activist, a Creator of RSS, Is Dead at 26, Apparently a Suicide." New York Times, January 12. Retrieved February 13, 2019 (https://www.nytimes.com/2013/01/13/ technology/aaron-swartz-internet-activist-dies-at-26.html).

Scroll Staff. 2018a. "Bhima Koregaon: Pune Court Sends Arun Ferreira, Vernon Gonsalves to Police Custody till November 6." Scroll.in, October 27. Retrieved February 13, 2019 (https:// scroll.in/latest/899855/bhima-koregaon-pune-court-sends-arun-ferreira-vernon-gonsalves-topolice-custody-till-november-6).

Scroll Staff. 2018b. "Tamil Nadu: At Least Nine Dead after Police Open Fire on Anti-Sterlite Protestors in Thoothukudi.” Scroll.in, May 22. Retrieved February 13, 2019 (https://scroll.in/ latest/879851/tamil-nadu-one-feared-dead-after-police-open-fire-on-anti-sterlite-protestors-inthoothukudi). 
Tipu, Sanaul Islam, Arifur Rahman Rabbi, and Afrose Jahan Chaity. 2017. "Farhad Mazhar Requests Court to Allow Him to go Back Home." Dhaka Tribune, July 4. Retrieved February 13, 2019 (https://www.dhakatribune.com/bangladesh/crime/2017/07/04/columnist-farhad-mazhartaken-adabor-police-station/).

\section{NOTES}

1. This special issue draws from a set of papers presented at the 2016 Feminist Preconference of the Annual Conference on South Asia in Madison, Wisconsin. The Preconference was organized by the author and Krupa Shandilya. In addition to the authors whose work is published in this special issue, presenters and discussants for the Preconference also included Sareeta Amrute, Anjali Arondekar, Pinky Hota, Rushaan Kumar, Ania Loomba, Geeta Patel, Kavita Philip, and Akhil Katyal. A panel on this theme was also held during the same year at the Law and Social Sciences Network (LASSNET) Conference in New Delhi. That panel included Rohit De, who is also a contributor to this volume, Aniruddhan Vasudevan, Gautam Bhan, and Nitya Vasudevan. The author thanks Dr. Shandilya and all of the presenters and discussants in both events, and Eric Beverley for last minute editing help on this introduction. The author also thanks the SAMAJ editorial board, especially Virginie Dutoya and Stéphanie Tawa Lama-Rewal, for their comments on this essay and for their generous editorial work in support of this special issue, and Francie Crebs, for wonderful editorial support.

2. I use the terms "feminist," "queer," and "trans*" throughout this introduction. While the status of the use of "feminist" in South Asia may be less in question today, the terms "queer" and "trans*" have both been critiqued for their potential valence in promoting an imaginary of sexuality and gender identity that conforms to certain identitarian norms, and looks ultimately to the West for their forms. My use of these terms here is not uncritical, taking cognizance of these critiques while also aiming to conform to certain norms of usage and legibility for a wide readership.

3. Large, public universities meant to provide broad access to higher education.

4. I use the term "Dalit" to describe both Vemula's caste affiliation and his Ambedkarite politics.

5. There have been overt and covert efforts to silence criticism of state policies at private Indian universities as well, induced by similar issues to those being raised here.

6. This introduction was written before the arrests of lawyers and advocates had taken place under the heading of the 2018 Bhima Koregaon protests (Johari et. al. 2018).

7. This is a fast changing landscape, with new incidents happening throughout India at an alarming rate. Since this writing, there has been widely reported violence against students by police at Banares Hindu College as well (See Express Web Desk 2019).

8. More recent engagements with questions of gender and caste are numerous. For example, please see the previous issue of SAMAJ, entitled "Caste-Gender Intersections in Contemporary India" (Ghosh and Banerjee 2018): https://journals.openedition.org/samaj/4574.

9. Aaron Schwartz was an "internet hacktivist" who had made thousands of JSTOR articles free for a period of time. His case is also referenced in the interview in this collection between Inderpal Grewal and Rohit De. Schwartz was arrested in 2011 and charged under the Computer Fraud and Abuse Act, and took his own life during court proceedings in 2013 (Schwartz 2013). 


\section{ABSTRACTS}

While there is a consensus that we are in a period of heightened official foreclosure of critical speech in South Asia, it would be wrong to presume that this historical period is exceptional in this regard. This special issue of SAMAJ takes up the ways in which laws against sedition and other laws controlling speech in South Asia are being used by the governments there with increasing frequency-against activists, lawyers and journalists. The issue is an examination of the uses of judicial and extrajudicial means to silence dissent throughout South Asia, and with an eye toward the historical precedents of particular contemporary instantiations of foreclosing and repressing critical speech. Here, we put these attempts at foreclosing criticism of the state in dialogue with the rise of new forms of public discourse and debate on gender and sexuality in South Asia, in order to pose a series of questions. What do questions of sexuality and gender identity have to do with revolutionary politics, with questions of class and political economy? Where are the spaces for radical critique constituted when there seems to be more space for different forms of gender and sexuality politics, sociality, and critique, and when the stakes of dissent seem to be climbing ever higher? Does it mean something in particular to have a queer feminist analysis, or to be queer or trans, in such times? Amongst these articles, the short answer to the last question is yes, but these meanings are multiple, and the grounds on which the politics of sexuality and gender rest are highly contested. Drawing on the longstanding history of feminist engagements with-and reliance on-the notion of dissent, and on work that interrogates the intersections of gender identity, sexuality and national belonging, this collection seeks to examine dissent, nationalism, and the politics of gender and sexuality within the frame of contemporary South Asia.

INDEX

Keywords: gender, sexuality, gender identity, feminism, dissent, sedition, law, South Asia

\section{AUTHOR}

\section{SVATI P. SHAH}

University of Massachusetts, Amherst; African Centre for Migration and Society (ACMS), University of Witwatersrand, and the Wits Institute for Social and Economic Research (WiSER), University of Witwatersrand 